\title{
Job Crafting Interventions: Systematic Review
}

\author{
Rita Pimenta de Devotto*, 1 \\ Orcid.org/0000-0002-2287-2526 \\ Solange Muglia Wechsler ${ }^{1}$ \\ Orcid.org/0000-0002-9757-9113
}

${ }^{1}$ Pontifícia Universidade Católica de Campinas, Campinas, SP, Brasil

\begin{abstract}
Job crafting is proactive bottom-up job redesign to optimize person-job fit. A job crafting intervention is any training or method designed to stimulate or develop job crafting behaviors in employees. This paper systematically reviews research examining the effects of job crafting interventions and identifies their tendencies and gaps. A search was conducted in PsycINFO, Academic Search Premier, Web of Science, and SciELO using the key terms job crafting and interventions in databases available from 2007 to September 2017. We identified eight studies that met our inclusion criteria. The analysis of these articles revealed that the design of seven intervention studies was based on theoretical assumptions derived from job demands-resources theory and used a quasi-experimental design. Job crafting interventions increased different types of job crafting behaviors, well-being variables, and job performance. Inconsistencies regarding significant effects in job resources and work engagement across studies are discussed. Recommendations for future research on job crafting interventions in organizations are presented.
\end{abstract}

Keywords: Job crafting, organizational interventions, systematic review, organizational behavior.

\section{Intervenções de Redesenho do Trabalho: Revisão Sistemática}

\section{Resumo}

O job crafting é o redesenho do trabalho, ascendente e proativo, para melhorar o ajuste entre o indivíduo e seu trabalho. As intervenções de job crafting são treinamentos ou métodos destinados a estimular ou desenvolver comportamentos de redesenho do trabalho nos empregados. Este artigo faz uma revisão sistemática da pesquisa sobre os efeitos das intervenções de job crafting e identifica suas tendências e lacunas. Consultamos as bases de dados PsycINFO, Academic Search Premier, Web of Science e SciELO, utilizando os descritores "job crafting" e "interventions", entre 2007 e setembro de 2017. Identificamos oito estudos que satisfizeram os critérios de inclusão. Sete estudos de intervenções quase experimentais basearam suas premissas no modelo teórico de Demandas e Recursos no Trabalho. As intervenções de job crafting aumentaram os diferentes tipos de comportamentos de job crafting, o bemestar e o desempenho no trabalho. As inconsistências sobre os efeitos significativos nos recursos do

* Mailing address: Rua das Abélias, 1952, Alphaville, Dom Pedro, Campinas - SP, Brazil 13097-173. E-mail: rpimentad@gmail.com 
trabalho e no engajamento no trabalho são discutidas. Recomendações para futuras pesquisas sobre intervenções de job crafting nas organizações são apresentadas.

Palavras-chave: Redesenho do trabalho, intervenções organizacionais, revisão sistemática, comportamento organizacional.

\section{Intervenciones de Job Crafting: Revisión Sistemática}

\section{Resumen}

El job crafting es el rediseño del trabajo, ascendente y proactivo, para mejorar el ajuste entre el individuo y su trabajo. Las intervenciones de job crafting son entrenamientos o métodos destinados a estimular o desarrollar comportamientos de rediseño del trabajo en los empleados. Este artículo hace una revisión sistemática de la investigación sobre los efectos de las intervenciones de job crafting e identifica sus tendencias y brechas. Consultamos las bases de dados PsycINFO, Academic Search Premier, Web of Science y SciELO, utilizando los descriptores "job crafting" y "interventions", entre 2007 y septiembre de 2017. Identificamos ocho estudios que cumplieron con los criterios de inclusión. Siete estudios de intervenciones casi experimentales basaron sus premisas en la teoría de las Demandas y Recursos en el Trabajo. Las intervenciones de job crafting aumentaron los diferentes tipos de comportamientos de job crafting, el bienestar y el rendimiento en el trabajo. Se discuten las inconsistencias sobre los efectos significativos en los recursos del trabajo y en el work engagement. Se presentan recomendaciones para futuras investigaciones sobre intervenciones de job crafting en las organizaciones.

Palabras clave: Job crafting, intervenciones organizativas, revisión sistemática, comportamiento organizacional.

Unstable economic environments, continuous and accelerating changes in organizational structures, growing uncertainty, and interdependence of workers are the characteristics of the previous decades (Grant \& Parker, 2009). Organizations must look for ways to outperform competitors, adapt and innovate for their effectiveness and long-term survival in their markets (Janssen, Van de Vliert, \& West, 2004). At the same time, there has been an increase in employee workload and pressure to work more efficiently (Demerouti, Xanthopoulou, Petrou, \& Karagkounis, 2017). Thus, modern organizations need proactive and engaged employees capable of creating and sustaining a healthy and motivating work environment (Sakuraya, Shimazu, Imamura, Namba, \& Kawakami, 2016; van den Heuvel, Demerouti, \& Peeters, 2015).

Traditional top-down interventions helped to successfully solve job design challenges but did not consider inadequacies related to personjob fit (Demerouti, 2015). Proactive perspectives on job redesign, which include employeeinitiated behaviors, have been proving to be a way to enhance job performance and well-being in organizations. Particularly, job crafting, a bottom-up individual job redesign alternative, has gained terrain and momentum in research and practice (Bakker, 2015; Vogt, Hakanen, Brauchli, Jenny, \& Bauer, 2016).

Job crafting refers to employees' selfinitiated changes to align their jobs with their personal strengths, passions, and values (Wrzesniewski, LoBuglio, Dutton, \& Berg, 2013) or to better optimize the level of job resources and job demands with their needs and abilities (Tims \& Bakker, 2010). Job crafting was originally defined as the individual bottomup process of making physical and cognitive changes in the task or relational boundaries at work (Wrzesniewski \& Dutton, 2001). Accordingly, job crafting consists of three types of strategies: (1) task crafting (e.g., actual alterations on the number or scope of tasks), (2) cognitive crafting (e.g., reframing meaning 
and identity at work), and (3) relational crafting (e.g., changes in the quantity and quality of workplace relationships). Task and relational crafting produce actual changes in the job characteristics and the social environment at workplace, whereas cognitive crafting relates to intangible (mental) changes in an individual's perception about their work's meaning and purpose (Lichtenthaler \& Fischbach, 2016). Since job crafting entails tangible changes in the demands and resources at work, Tims and Bakker (2010) proposed its integration into the job demand-resources (JD-R) theory (Bakker \& Demerouti, 2017) and offered an alternative job crafting conceptualization.

The JD-R theory explains and predicts employee well-being and job performance in all work environments. The JD-R model includes specific propositions regarding interactions between job demands and (job and personal) resources, self-starting behaviors (e.g., job crafting and self-undermining) and outcomes (e.g., work engagement and job performance). Job demands are the most important predictors of job strain (e.g., exhaustion, health complaints, job-related anxiety) whereas job resources are the main predictors of the motivational process (e.g., work engagement, commitment, flourishing). Job resources mitigate the negative effect of job demands on strain and, particularly, influence motivation when job demands are high. Personal resources (e.g., self-efficacy, optimism) have a direct positive effect on work engagement and are expected to play a similar role as job resources. Motivation has a positive impact, whereas job strain has a negative impact on job performance (Bakker \& Demerouti, 2017).

Within the JD-R model, job crafting was conceptualized as a bottom-up individual job redesign strategy to optimize the level of job demands and job resources at work (Tims \& Bakker, 2010). Job crafting mediates the relationship of resources (job and personal) and demands with work engagement, and it is positioned as a predictor of work engagement and job performance. Within JD-R perspective, job crafting was operationalized in the forms of (1) increasing social job resources (e.g., asking for feedback), (2) increasing structural job resources (e.g., increasing autonomy), (3) increasing challenging job demands (e.g., starting new projects) and (4) decreasing hindering job demands (e.g., reducing workload; Tims, Bakker, \& Derks, 2012). Thus, in the JD-R conceptualization of job crafting, changing job demands is a form of task crafting and changing (structural and social) job resources, all of which can be seen as a type of relational crafting. Cognitive crafting is harder to frame in the JD-R perspective, as it is focused on an employee inner-self rather than on actual behavior (Demerouti, 2014).

Despite these similarities, both conceptualizations view the purposes and motives of job crafting differently. The former conceptualization considers that job crafting aims to increase work identity and meaningfulness at work, gained through actual changes in job characteristics and cognitive changes in employee's work perception (Wrzesniewski \& Dutton, 2001). The latter JD-R conceptualization of job crafting emphasizes crafting behaviors as active coping to deal with stress at work (Tims et al., 2012). Crafting behaviors aim to protect individual health and to increase motivation through tangible changes in job characteristics (Lichtenthaler \& Fischbach, 2016; Niessen, Weseler, \& Kostova, 2016). Based on both job crafting theoretical formulations, different measures were developed to assess the construct. Some researchers have developed measurement instruments fully based on Wrzesniewski and Dutton's (2001) three dimensions construct (i.e., task crafting, cognitive crafting, relational crafting; e.g., Niessen et al., 2016; Slemp \& Vella-Brodrick, 2014). In parallel, other measures operationalized the construct based on Tims and Bakker (2010) conceptualization, grounded in the JD-R framework (e.g., Nielsen \& Abildgaard, 2012; Petrou, Demerouti, Peeters, Schaufeli, \& Hetland, 2012; Tims et al., 2012). Since the emergence of these valid and reliable measures, several studies have been published. A recent meta-analysis concluded that the most widely adopted theoretical model of job crafting is the one proposed by Tims and Bakker (2010), 
which positioned job crafting in the JD-R model (Rudolph, Katz, Lavigne, \& Zacher, 2017).

Although job crafting behaviors focus primarily on improving individual situation at work, research over the past decade has provided evidence that job crafting is an alternative approach to job redesign, due to its effectiveness (Bakker \& Demerouti, 2017). Evidence of the positive outcomes of job crafting behaviors is accumulating and scholars agree that job crafting can be a promising tool to increase work engagement (Vogt et al., 2016), job performance (Bakker, 2015; van Wingerden, Bakker, \& Derks, 2016) and well-being (Slemp \& Vella-Brodrick, 2014). Besides, job crafting refers to employees' self-initiated actions to increase person-job fit; it can be facilitated by management through feedback (Wrzesniewski, 2003) or supported by interventions (Bakker, 2015).

Positive psychological interventions in organizations can be an effective strategy for increasing employee well-being and job performance (Meyers, van Woerkom, \& Bakker, 2013). In this line, intervention studies which stimulated job crafting behaviors on employees produced positive effects in employee well-being and job performance (Bakker \& Demerouti, 2017). Current literature on job crafting proposed field studies to evaluate the effects of job crafting interventions at work. A job crafting intervention is any intentional activity or method designed to stimulate or develop job crafting behaviors in employees to evaluate its effects on outcomes of interest. Job crafting interventions can also be part of a more general positive psychology intervention (Meyers et al., 2013) as it happens in combination with other kinds of interventions, such as interventions aimed at developing personal resources (van Wingerden et al., 2016; van Wingerden, Derks, \& Bakker, 2017).

Research that seeks to evaluate the impact of job crafting interventions on individual and organizational outcomes is still scarce; however, evidence is accumulating regarding the differential effectiveness of stimulated job crafting behaviors (van Wingerden, Bakker, \& Derks, 2017a). Although incipient, the research on job crafting interventions is promising, as it helps to uncover what employees do to alter their job characteristics and work meaningfulness, and the impact of such individual job crafting behaviors on well-being and job performance (Bakker \& Demerouti, 2017). To the best of our knowledge, there was no literature review that focused specifically on examining the effects of job crafting interventions. Therefore, we present a systematic review that summarizes the findings of empirical quantitative studies examining the effects of job crafting interventions in organizations. We aim to offer a general and critical overview of the interventions and propose the research question: What are the benefits of job crafting interventions and which tendencies and gaps can be identified?

\section{Method}

\section{Selection Criteria}

Studies were included if they met the following criteria: (1) provided an experimental or quasi-experimental research design of a job crafting intervention tested in a working context, (2) used pre and post intervention measures, (3) were published during 2007 until September 2017 as job crafting measures only emerged from 2007 onwards, and (4) we limited the search to articles written in English, published in peer- reviewed journals.

\section{Sample}

We gained access to the electronic databases through the Brazilian virtual library Portal de Periódicos da Coordenação de Aperfeiçoamento de Pessoal de Nivel Superior - CAPES. We performed the search at four electronic international databases: PsycINFO (American Psychological Association), Academic Search Premier - ASP (EBSCOhost), Web of Science, and SciELO. The key words used were: "job crafting" in the field "abstract," the Boolean operator "AND," "interventions" in the field "abstract" ("topics" field for Web of Science database). 


\section{Procedure}

This initial search resulted in 40 records: 23 hits in Web of Science, 12 in PsycINFO, 5 in ASP, and none in SciELO. Subsequently, based on the abstracts of the selected articles, duplicates $(n=9)$ were removed. The authors analyzed the remaining 31 records, using the selected criteria mentioned above. Authors excluded 23 records due to misfit criteria. Finally, eight full-text articles were assessed for eligibility and were included in the qualitative synthesis. Two studies (van Wingerden et al., 2016; van Wingerden et al., 2017) examined the impact of a job crafting interventions combined with personal resources intervention and were part of this selection.

\section{Data Analysis}

Our research question consisted of two parts: (a) the outcomes of the job crafting interventions, and (b) tendencies and gaps identified. Thus, we analyzed the eight studies for sample, assessment, measures used, research design, effects on outcomes, and limitations identified by authors. Specifically, the outcomes were organized under the job demands-resources model (JD-R) broader categories: personal resources, job resources, job demands, job crafting, motivation, strain, and job performance (Bakker \& Demerouti, 2017). The outcomes were summarized across all studies and significant effects of interventions identified. Thereafter, based on the contributions and limitations acknowledged by authors, we identified tendencies and gaps common to the job crafting intervention studies.

\section{Results}

Table 1 provides information regarding sample, types of job crafting behaviors assessed and measures used in the job crafting intervention studies. The search resulted in eight articles with a total sample of 601 participants (average sample size $n=75$ ). Results showed a concentration of studies in the Netherlands, as six out of eight studies were held there, corresponding to $81 \%$ of total occupational sample. One study was carried out in Greece's public sector during austerity-led organizational changes (i.e., lay-offs, reorganizations, cuts in costs, salary reductions; Demerouti et al., 2017) and one study was carried out in Japan's private sector (Sakuraya et al., 2016). Studies also showed a concentration of authorship with institutional affiliation in the Netherlands. Diversity of occupational group sample was modest: teachers, employees, managers, police officers, and healthcare professionals.

In total, 12 different forms of job crafting behaviors were assessed among the eight studies. Seven studies were based on the theoretical approach of job crafting as conceptualized within the JD-R model (Tims \& Bakker, 2010; Tims et al., 2012). Thus, job crafting was mainly assessed by instrument measures grounded in the JD-R framework: Job crafting Scale (i.e., JCS $^{1}$ ) by Petrou et al. (2012), Job Crafting Scale (i.e., $\mathrm{JCS}^{3}$ ) operationalized by Tims and Bakker (2010) and one study presented a new scale specifically constructed to measure two forms of job crafting behavior, toward interests and strengths (Kooij, van Woerkom, Wilkenloh, Dorenbosh, \& Denissen, 2017). One study assessed job crafting according Wrzesniewski and Dutton's (2001) three-dimensional construct (Sakuraya et al., 2016).

All eight studies measured the effects of the interventions on variables of the broad JD-R theory's categories (Bakker \& Demerouti, 2017). Therefore, a variety of measures were used to assess the different variables in each category. The Utrecht Work Engagement Scale - short version (UWES-9 items) was the most used instrument, as five studies measured work engagement as an outcome of interest.

Table 2 summarizes the research design elements of the eight studies. Seven of these studies were quasi-experimental designs with control groups; just one study was longitudinal and analyzed the long-term effect of a job crafting intervention (van Wingerden et al., 2017b). All eight job crafting interventions took place in the employee's own work context, and all were carried out within one to three training sessions for minimum of three hours and maximum of 12 hours. Training sessions were always combined 
Table 1

Sample, Types of Job crafting Behaviors Assessed and Measures in Job Crafting Interventions Studies

\begin{tabular}{|c|c|c|c|}
\hline Study & $\begin{array}{l}\text { Country/ Total sample/Intervention } \\
\text { group sample }\end{array}$ & $\begin{array}{c}\text { Types of Job } \\
\text { crafting assessed }\end{array}$ & Measures \\
\hline $\begin{array}{l}\text { van den Heuvel } \\
\text { et al. (2015) }\end{array}$ & $\begin{array}{l}\text { Netherlands }(N=86) \\
\text { Police officers }(n=39)\end{array}$ & SCD; SJR; RD & $\begin{array}{l}\mathrm{JCS}^{1} \text {; Opportunities for development } \\
\text { items; LXM; JAWS; Self-efficacy items }\end{array}$ \\
\hline $\begin{array}{l}\text { Sakuraya } \\
\text { et al. }(2016)\end{array}$ & $\begin{array}{l}\text { Japan }(N=42) \\
\text { Managers }\end{array}$ & $\mathrm{TC} ; \mathrm{CC} ; \mathrm{RC}$ & $\mathrm{JCS}^{2}$; UWES; BJSQ \\
\hline $\begin{array}{l}\text { van Wingerden } \\
\text { et al. (2016) }\end{array}$ & $\begin{array}{c}\text { Netherlands }(N=67) \\
\text { Healthcare professionals }(n=43)\end{array}$ & $\begin{array}{l}\text { IStrJR; ISocJR; } \\
\text { ICJD; }\end{array}$ & $\begin{array}{l}\mathrm{JCS}^{3} \text { subscales; PsyCap subscales, } \\
\text { UWES; In-role performance scale }\end{array}$ \\
\hline $\begin{array}{l}\text { Demerouti } \\
\text { et al. }(2017)\end{array}$ & $\begin{array}{c}\text { Greece }(N=72) \\
\text { Employees }(n=30)\end{array}$ & SCD; SJR; RD & $\begin{array}{c}\mathrm{JCS}^{1} \text {; JAWS; Openness to change items; } \\
\text { Adaptive performance items; Individuals } \\
\text { assessment of change }\end{array}$ \\
\hline $\begin{array}{l}\text { Kooij et al. } \\
\text { (2017) }\end{array}$ & $\begin{array}{l}\text { Netherlands }(N=86) \\
\text { Employees }(n=31)\end{array}$ & $\begin{array}{l}\text { JC-strengths } \\
\text { JC-interests }\end{array}$ & PJ-Fit; JC-strengths; JC-interests \\
\hline $\begin{array}{l}\text { van Wingerden } \\
\text { et al. }(2017 \mathrm{a})\end{array}$ & $\begin{array}{l}\text { Netherlands }(N=71) \\
\text { Teachers }(n=41)\end{array}$ & $\begin{array}{l}\text { IStrJR; ISocJR; } \\
\text { ICJD }\end{array}$ & $\mathrm{JCS}^{3}$; W-BNS; UWES \\
\hline $\begin{array}{l}\text { van Wingerden, } \\
\text { Bakker, \& } \\
\text { Derks }(2017 b)\end{array}$ & $\begin{array}{l}\text { Netherlands }(N=75) \\
\text { Teachers }(n=45)\end{array}$ & $\begin{array}{l}\text { IStrJR; ISocJR; } \\
\text { ICJD; DHJD }\end{array}$ & $\begin{array}{l}\mathrm{JCS}^{3} \text {; Workload subscale; Emotional } \\
\text { demand subscale; Performance feedback } \\
\text { subscale; Opportunities for professional } \\
\text { development subscale; Resilience } \\
\text { subscale; Self-efficacy subscale; UWES; } \\
\text { In-role performance scale. }\end{array}$ \\
\hline $\begin{array}{l}\text { van Wingerden } \\
\text { et al. (2017) }\end{array}$ & $\begin{array}{l}\text { Netherlands }(N=102) \\
\text { Teachers }(n=58)\end{array}$ & $\begin{array}{l}\text { IStrJR; ISocJR; } \\
\text { ICJD; DHJD }\end{array}$ & $\begin{array}{c}\mathrm{JCS}^{3} ; \mathrm{UWES} ; \\
\text { In-role performance scale }\end{array}$ \\
\hline
\end{tabular}

Note. Types of Job crafting assessed: SCD = Seeking challenge demands; SJR = Seeking job resources; RD = Reducing demands; $\mathrm{TC}=$ Task crafting; $\mathrm{CC}=$ Cognitive crafting; $\mathrm{RC}=$ Relational crafting; JC-strengths = Job crafting toward strengths; JC-interests $=$ Job crafting toward interests; IStrJR = Increasing structural job resources; DHJD = Decreasing hindering job demands; ISocJR = Increasing social job resources; ICJD = Increasing challenging job demands. Measures: JCS1= Job Crafting Scale (Petrou et al., 2012); LMX = Leader-member exchange; JAWS = Job Affective Well-being Scale; JCS2 = Job crafting (Sekiguchi, Jie, \& Hosomi, 2014); UWES (9-items) = Utrecht Work Engagement Scale; BJSQ = Brief Job Stress Questionnaire; PJ-Fit = Person-Job Fit; JC-strengths $=$ Job crafting toward strengths; JC-interests $=$ Job crafting toward interests; JCS3 $=$ Job Crafting Scale (Tims et al., 2012); PsyCap = Psychological capital; W-BNS = Work-Related Basic need Satisfaction.

with the set-up of a self-chosen job crafting plan. Participants worked on achieving their personal job crafting goals in their work environment during a maximum of four weeks. In only one of the studies, training sessions were conducted outside of working hours (Sakuraya et al., 2016). Two studies included a personal resources training session combined with a job crafting training session to test the effects of both interventions on outcomes of interest (van Wingerden et al., 2016; van Wingerden et al., 2017).

Table 3 presents the effect of the interventions on the outcomes of interest, organized according the JD-R theory broad categories: job crafting behaviors, personal resources, job resources, job demands, motivation, strain, and job performance (Bakker \& Demerouti, 2017). The variables in the motivation and strain categories were merged into one group and labeled as occupational well-being (Table 3). Results reveal that studies measured the effects of job crafting interventions in a variety of outcomes under these broad categories.

A consistent finding in the eight studies was the significant increases in at least one type of job crafting behavior after the interventions, 
Table 2

Study Research Design Elements of Job Crafting Interventions

\begin{tabular}{|c|c|c|c|}
\hline Study & Assessment & Intervention & Control condition \\
\hline $\begin{array}{l}\text { van den Heuvel et } \\
\text { al. (2015) }\end{array}$ & Pre, post & $\begin{array}{l}\text { Two training sessions ( } 8 \mathrm{~h} \text { and } 4 \mathrm{~h} \text { ) } \\
\text { with a } 4-\text { week interval between them. }\end{array}$ & $\begin{array}{l}\text { Police officers } \\
\quad(n=47)\end{array}$ \\
\hline $\begin{array}{l}\text { Sakuraya et al. } \\
\qquad(2016)\end{array}$ & $\begin{array}{l}\text { Pre, post, } 1 \text { month } \\
\text { follow up }\end{array}$ & $\begin{array}{l}\text { Two training sessions }(2 \mathrm{~h} \text { each }) \\
\text { with a } 2 \text {-week interval between them. }\end{array}$ & No control group \\
\hline $\begin{array}{l}\text { van Wingerden et } \\
\text { al. (2016) }\end{array}$ & Pre, post & $\begin{array}{l}\text { Two training sessions ( } 8 \mathrm{~h} \text { and } 4 \mathrm{~h} \text { ) } \\
\text { with a } 4-\text { week interval between them. }\end{array}$ & $\begin{array}{l}\text { Healthcare professionals } \\
\qquad(n=24)\end{array}$ \\
\hline $\begin{array}{l}\text { Demerouti et al. } \\
\qquad(2017)\end{array}$ & Pre, post & One training session $(3 \mathrm{~h})$. & $\begin{array}{l}\text { Employees } \\
\quad(n=42)\end{array}$ \\
\hline Kooij et al. (2017) & Pre, post & $\begin{array}{l}\text { One training session }(4 \mathrm{~h}) \text { and individual } \\
\text { call to check goal accomplishment. }\end{array}$ & $\begin{array}{l}\text { Waiting-list control group } \\
\qquad(n=55)\end{array}$ \\
\hline $\begin{array}{l}\text { van Wingerden et } \\
\text { al. }(2017 \mathrm{a})\end{array}$ & Pre, post & $\begin{array}{l}\text { Two sessions }(8 \mathrm{~h} \text { and } 4 \mathrm{~h}) \\
\text { with a } 4 \text {-week interval between them. }\end{array}$ & $\begin{array}{l}\text { Teachers } \\
(n=30)\end{array}$ \\
\hline $\begin{array}{l}\text { van Wingerden et } \\
\text { al. }(2017 \mathrm{~b})\end{array}$ & $\begin{array}{c}\text { Pre, post, } 1 \text { year after } \\
\text { post }\end{array}$ & $\begin{array}{l}\text { Two sessions }(8 \mathrm{~h} \text { and } 4 \mathrm{~h}) \\
\text { with a } 4 \text {-week interval between them. }\end{array}$ & $\begin{array}{l}\text { Teachers } \\
(n=30)\end{array}$ \\
\hline $\begin{array}{l}\text { van Wingerden et } \\
\text { al. (2017) }\end{array}$ & Pre, post & $\begin{array}{l}\text { Three training sessions over } \\
\text { a period of } 4 \text { weeks. }\end{array}$ & $\begin{array}{l}\text { Teachers } \\
(n=18)\end{array}$ \\
\hline
\end{tabular}

compared with the control conditions. Job crafting as a single measure was found to significantly increase in three studies out of four that assessed it as an integrated construct. Results of the analysis of the separate job crafting behavior components revealed 12 significant increases $(+)$, two significant decreases $(-)$, and nine no significant effects (ns) on job crafting behavior components.

Specifically, significant increases were reported on one occasion at cognitive crafting (CC), increasing social job resources (ISocJR), and job crafting toward strengths in older works (JC-strengths). Increasing structural job resources (IStrJD) and increasing challenging job demands (ICJD) were found to significantly increase in three studies. Decreasing hindering job demands component (DHJD) increased in one study after the intervention, where it was also the most popular job crafting goal among participants $(87.5 \%$ of employees chose to decrease a hindering demand as a job crafting goal; van Wingerden et al., 2017). Reducing demands (RD) significantly increased after an intervention that took place in an organizational austerity context (Demerouti et al., 2017). In contrast, DHJD was found to decrease over time in the longitudinal study. The authors explained that participants actively tried to decrease their hindering job demands shortly after the intervention, not only because they gained awareness of them, but because they put less effort into reducing hindering demands one year after the intervention (van Wingerden et al., 2017b).

Regarding the other outcomes of interest, results showed that researchers were more concerned about measuring changes in the level of personal resources than assessing changes on the level of job demands and job resources. Favorable increases on personal resources were found in four studies out of five that measured at least one variable in this category (e.g., openness to change, basic need satisfaction, self-efficacy, psychological capital). However, two of them (van Wingerden et al., 2016; van Wingerden et al., 2017) combined training sessions about personal resources with a job crafting 
Table 3

Effects of Job Crafting Interventions on Outcomes of Interest by Category of the JD-R Model

\begin{tabular}{|c|c|c|c|c|c|c|}
\hline Study & $\begin{array}{l}\text { Job crafting } \\
\text { behaviors }\end{array}$ & $\begin{array}{l}\text { Personal } \\
\text { Resources }\end{array}$ & $\begin{array}{c}\text { Job } \\
\text { Resources }\end{array}$ & $\begin{array}{c}\text { Job } \\
\text { Demands }\end{array}$ & $\begin{array}{l}\text { Occupational } \\
\text { well-being }\end{array}$ & $\begin{array}{c}\text { Job } \\
\text { performance }\end{array}$ \\
\hline $\begin{array}{l}\text { van den Heuvel } \\
\text { et al. (2015) }\end{array}$ & $\mathrm{JCB}(\mathrm{ns})$ & $\begin{array}{l}\text { Self-efficacy } \\
\text { (ns) }\end{array}$ & $\begin{array}{l}\text { OD (ns) } \\
\operatorname{LMX}(n s)\end{array}$ & $\mathrm{Nm}$ & $\begin{array}{l}\text { PA (ns) } \\
\text { NA (ns) }\end{array}$ & $\mathrm{Nm}$ \\
\hline $\begin{array}{l}\text { Sakuraya et al. } \\
\qquad(2016)\end{array}$ & $\begin{array}{l}\mathrm{JCB}(+) \\
\mathrm{CC}(+) \\
\mathrm{TC}(\mathrm{ns}) \\
\mathrm{RC}(\mathrm{ns})\end{array}$ & $\mathrm{Nm}$ & $\mathrm{Nm}$ & $\mathrm{Nm}$ & $\begin{array}{l}\text { WE }(+) \\
\operatorname{PD}(-)\end{array}$ & $\mathrm{Nm}$ \\
\hline $\begin{array}{l}\text { van Wingerden } \\
\text { et al. (2016) }\end{array}$ & $\begin{array}{c}\mathrm{JCB}(+) \operatorname{IStrJR}(+) \\
\operatorname{ISocJR}(\mathrm{ns}) \operatorname{ICJD}(+)\end{array}$ & PsyCap (+) & $\mathrm{Nm}$ & $\mathrm{Nm}$ & WE $(+)$ & $\operatorname{IRP}(+)$ \\
\hline $\begin{array}{l}\text { Demerouti et al. } \\
\qquad(2017)\end{array}$ & $\begin{array}{l}\mathrm{SR}(\mathrm{ns}) \\
\mathrm{RD}(+)\end{array}$ & $\begin{array}{l}\text { Openness to } \\
\text { change }(+)\end{array}$ & $\mathrm{Nm}$ & $\mathrm{Nm}$ & $\mathrm{PA}(+)$ & $\mathrm{AP}(+$ and -$)$ \\
\hline $\begin{array}{l}\text { Kooij et al. } \\
\quad(2017)\end{array}$ & $\begin{array}{l}\text { JC-interests (ns) } \\
\text { JC-strengths for } \\
\text { older works }(+) \\
\text { JC-strengths for } \\
\text { younger workers }(-)\end{array}$ & $\mathrm{Nm}$ & $\mathrm{Nm}$ & $\mathrm{Nm}$ & PJ-Fit (ns) & $\mathrm{Nm}$ \\
\hline $\begin{array}{l}\text { van Wingerden } \\
\text { et al. (2017a) }\end{array}$ & $\begin{array}{c}\text { ICJD (+) } \\
\text { IStrJR (ns) } \\
\text { ISocJR (ns) }\end{array}$ & $\begin{array}{c}\text { Basic need } \\
\text { satisfaction }(+)\end{array}$ & $\mathrm{Nm}$ & $\mathrm{Nm}$ & WE $(+)$ & $\mathrm{Nm}$ \\
\hline $\begin{array}{l}\text { van Wingerden } \\
\text { et al. }(2017 \mathrm{~b})^{*}\end{array}$ & $\begin{array}{c}\operatorname{JCB}(+) \\
\operatorname{DHJD}_{\mathrm{T} 2}(+) \\
\operatorname{DHJD}_{\mathrm{T} 3}(-) \\
\operatorname{IStrJR}_{(+)} \\
\operatorname{ISocJR}(n s)_{\operatorname{ICJD}_{\mathrm{T} 2}(+)} \\
\operatorname{ICJD}_{\mathrm{T} 3}(\mathrm{~ns})\end{array}$ & $\begin{array}{l}\text { Self-efficacy }(+) \\
\text { Resilience (ns) }\end{array}$ & $\begin{array}{l}\mathrm{PF}(+) \\
\mathrm{OD}(+)\end{array}$ & $\begin{array}{c}\text { Level of Job } \\
\text { demands } \\
\text { (ns) }\end{array}$ & WE (ns) & $\mathrm{JP}(+)$ \\
\hline $\begin{array}{l}\text { van Wingerden } \\
\text { et al. (2017) }\end{array}$ & $\begin{array}{l}\text { DHJD (+) } \\
\text { IStrJR (+) } \\
\text { ISocJR (+) } \\
\text { ICJD (ns) }\end{array}$ & $\mathrm{Nm}$ & $\mathrm{Nm}$ & $\mathrm{Nm}$ & WE (ns) & $\begin{array}{c}\operatorname{IRP}(\mathrm{ns}) \\
\operatorname{IRP}+\mathrm{PR}(+)\end{array}$ \\
\hline
\end{tabular}

Note $(+)=$ significant increase, $(-)=$ significant decrease, $(\mathrm{ns})=$ not significant, $($ as $)=$ approaches significance. $\mathrm{Nm}=\mathrm{Not}$ measured. Job crafting behaviours: JCB = Job crafting behaviors; TC $=$ Task crafting; CC = Cognitive crafting; $\mathrm{RC}=\mathrm{Re}-$ lational crafting; IStrJR = Increasing structural job resources; ISocJR = Increasing social job resources; ICJD = Increasing challenging job demands; DHJD = Decreasing hindering job demands; $\mathrm{SR}=$ Seeking resources; $\mathrm{RD}=$ Reducing demands; JC-strengths $=$ Job crafting toward strengths; JC-interests $=$ Job crafting toward interests. Job Resources: OD = Opportunities for development; $\mathrm{LXM}=$ Leader member exchange; $\mathrm{PF}=$ Performance feedback; $\mathrm{OD}=$ Opportunities for development. Occupational well-being: $\mathrm{PA}=$ Positive affect; NA = Negative affect; $\mathrm{WE}=$ Work engagement; $\mathrm{PD}=$ Psychological Distress; PJ-Fit = Person-Job Fit. Job performance: IRP = in-role performance; AP = Adaptive Performance; IRP+ PR = in-role performance when job crafting intervention was combined with personal resources intervention. ${ }^{*}$ Longitudinal study: measures reported in 1 week after intervention (T2) and 1 year after intervention (T3).

intervention. Positive effects on job resources were reported in one study (van Wingerden et al., 2017b), but only two studies were concerned with the impact of the interventions on the level of job resources.
Measures regarding motivation and strain (JD-R categories) were grouped under the label occupational well-being outcomes. Work engagement was the most measured outcome in this category: three out of five studies found 
positive increases on work engagement. Contrary to the expected, two studies found no significant effects. Interventions also reduced psychological distress (Sakuraya et al., 2016) and increased positive affect (Demerouti et al., 2017).

Results were more consistent across the four studies that measured the impact of job crafting interventions on job performance. Interventions were effective in increasing job performance (van Wingerden et al., 2017b), inrole performance (van Wingerden et al., 2016; van Wingerden et al., 2017) and had an indirect positive effect on adaptive performance through positive affect (Demerouti et al., 2017). On the other hand, significant decreases on adaptive performance were observed among employees who assessed organizational changes negatively and had their job demands reduced (Demerouti et al., 2017).

The authors of these eight studies acknowledged some limitations with the research designs of their intervention studies. Results of our analysis showed mainly five types of research design limitations. First, six studies pointed homogeneous occupational group as a main research design limitation as it restricted the generalizability of the findings. Second was the short time (from one up to five weeks) of the post measurement adopted. Authors of six studies acknowledged that they could not be sure whether the effects found were long lasting or short lived (Demerouti et al., 2017) and whether employees would continue to craft their jobs once the intervention had ended (van den Heuvel et al., 2015). Third, the lack of a randomized control trial was a limitation in five studies. The quasi-experimental design without randomly assigning participants to the conditions may have prevented the identification of the intervention effects due to the differences between the groups at the beginning of the intervention, or due to a result of these interventions. Fourth, the modest sample size was a limitation in five studies. This may have led to low statistical power and inflated estimates effect sizes (van Wingerden et al., 2017). Lastly, was the use of selfreport measures only because they could have resulted in common method biases (Demerouti et al., 2017; van den Heuvel et al., 2015; van Wingerden et al., 2016) and were unable to provide an objective view of improvements and changes in the observable behaviors.

\section{Discussion}

This paper presents a first systematic review that summarizes the findings of job crafting interventions in organizational contexts. We identified and analyzed the outcomes of job crafting interventions as well as the tendencies and gaps among the eight studies reviewed. Although job crafting is based on self-initiated actions (Tims \& Bakker, 2010; Wrzesniewski \& Dutton, 2001) it can be facilitated or promoted by organizational interventions (Bakker, 2015). There is accumulating evidence that employee job crafting behavior and other positive outcomes at work can be increased through job crafting interventions.

Our findings reveal that job crafting interventions were effective in stimulating participants to engage in different types of crafting behaviors. The JD-R theory (Bakker \& Demerouti, 2017) was the predominant framework for assessing job crafting behaviors. All the significant effects found in the different types of job crafting behaviors were in line with the JD-R theory. Overall, increasing structural job resources was an important strategy for gaining resources, and was considered as a preferred job crafting strategy (van Wingerden et al., 2017). The JD-R theory positioned job crafting as an important self-starting behavior for creating a resourceful work environment that in turn helps boost work engagement (Bakker \& Demerouti, 2017). In this review, evidence of favorable effects on increasing structural job resources strengthen this proposition.

Also in line with the JD-R theory, crafting to reduce demands (e.g., DHJD and RD) was a helpful strategy (1) to maintain individual's health (van Wingerden et al., 2017), and (2) to keep individual's successful functioning under unfavorable working conditions due to austerity measures (Demerouti et al., 2017). The JD-R theory posits that job demands play 
a crucial role in the health-impairment process (e.g., exhaustion, health complaints, etc.) but does not instigate the motivational process (e.g., work engagement). Reducing demands had no effect on work engagement (van Wingerden et al., 2017), but had a positive impact on adaptive performance of the employees who assessed organizational changes positively (Demerouti et al., 2017).

Job crafting behaviors were also analyzed based on the original model of job crafting conceptualized by Wrzesniewski and Dutton (2001). A significant favorable effect on cognitive crafting suggested that this type of job crafting may precede task and relational crafting and promote work engagement. Task and relational crafting require individuals to change their actual behavior at work and may take more time to happen than cognitive crafting (Sakuraya et al., 2016). Following this original conceptualization of job crafting, an array of antecedents and outcomes of each job crafting dimension (i.e., task, cognitive, and relational crafting, can be further explored by researchers).

Findings also revealed contradictions regarding the effect of interventions in some job crafting behaviors. Contrary to the expected, there were no significant effects on task crafting (TC), relational crafting (RC), and job crafting toward interests (JC-interests). Findings were also inconsistent across studies, ranging from no significant effects to positive increases, on increasing challenging demands (ICJD) and on increasing social job resources (IsStrJR). Such contradictions and inconsistencies were evidence that not all types of job crafting were developed through interventions. Reasons for that may reside in: (1) limitations of research designs (e.g., timeframe of post intervention measurement to capture actual changes in behavior, such as task crafting; Sakuraya et al., 2016), (2) situational conditions across different occupational groups which may affect these different types of job crafting (e.g., teachers and healthcare professionals have few opportunities to increase their social job resources at work; van Wingerden et al., 2016; van Wingerden et al., 2017a), and (3) individual factors (e.g., age as a critical condition that moderates the effect of the job crafting interventions; Kooij et al., 2017). Thus, more research is needed to elucidate which types of job crafting behaviors are more affected by interventions and which conditions encourage them.

Studies also brought evidence of significant increases in levels of personal resources (e.g., self-efficacy, basic need satisfaction, openness to change), job resources (e.g., opportunities for development, performance feedback), motivation (e.g., work engagement), well-being, (e.g., positive affect) and performance (e.g., adaptive performance, job performance, in-role performance). Job crafting interventions also led to decreases in strain (e.g., psychological distress and negative affect). However, no significant effects were found in personal resources (e.g., resilience), job resources (e.g., leader-member exchange), level of job demands, and work engagement.

Particularly, we call attention the inconsistency of significant effects on work engagement, as only three out of five job crafting interventions led to favorable effects on work engagement. Work engagement is a positive, fulfilling, work-related state of mind characterized by vigor, dedication, and absorption (Schaufeli \& Taris, 2014). Work engagement has been found to be a predictor of job performance and has been considered an important occupational well-being indicator (Bakker, 2015). Thus, it is important to uncover how job crafting interventions can foster work engagement by selecting relevant job demands and resources to craft (Bakker \& Demerouti, 2017). In this review, we observed that the three types of interventions that had a positive impact on work engagement were oriented to the gain of resources and to increase meaning at work. These interventions focused on stimulating cognitive crafting (Sakuraya et al., 2016), increasing job resources (van Wingerden et al., 2017a), or combining a job crafting training session with personal resources training session (van Wingerden et al., 2016). In contrast, the intervention studies in which participants focused mainly on decreasing hindering job demands 
(van Wingerden at al., 2017b; van Wingerden at al., 2017) had no significant effects on work engagement. Therefore, these findings suggest that to foster work engagement through job crafting interventions, it is necessary to stimulate certain types of crafting behaviors oriented to gain resources and to increase meaningfulness at work.

We found four tendencies and their related gaps in the eight intervention studies analyzed. First, JD-R conceptualization of job crafting was the predominant framework, which led to the measurement of behaviors in terms of changes in the levels of job resources and demands. On the other hand, only two studies posited job crafting as an individual strategy to increase work identity and meaningfulness at work (Wrzesniewski \& Dutton, 2001) and measured it according to this conceptualization. Thus, we consider that there is an imbalance regarding the two conceptualizations of job crafting used by researchers, which reflects the lack of measurement of specific types of job crafting behaviors. Particularly, we suggest that the role of cognitive crafting should not be neglected from scholars and deserve more attention in research. Crafting cognitions are an important way in which employees can shape their work experience and build a positive identity at work (Wrzesniewski \& Dutton, 2001). Through cognitive crafting employees can appreciate the broader effects of their work (e.g., in the organization and community) and the purpose the job holds in their lives (Slemp \& VellaBrodrick, 2014).

A second tendency was the joint training sessions with the execution of a personal job crafting plan with clear goals formulated by participants themselves. This combined practice facilitated and amplified the learning transfer (van Wingerden, 2017a). Furthermore, reflection exercises (e.g., job-person analysis) and the group process (e.g., sharing of job crafting experiences) were important elements in all eight job crafting interventions reviewed here. This kind of intervention script could be improved toward a more continuous process by adding a close digital monitoring (van den
Heuvel et al., 2015) or phone calls (Kooij et al., 2017) to discuss the accomplishment of personal job crafting plans and to address any hindering factors.

Third, authors acknowledged that the shortterm measurement of outcomes could have prevented the observation of more significant effects. Interestingly, the solely longitudinal study reported that the significant effect of the intervention on increasing personal resources (e.g., self-efficacy) and job resources (e.g., performance feedback, opportunities for professional development) only took place one year after the job crafting intervention. This delayed effect suggested that increased job crafting behaviors may have not shown immediate effects on outcomes (van Wingerden et al., 2017). It may take time to transfer new acquired skills (e.g., how to increase structural job resources) or to transform new perceptions about work meaning into actions in real life job situations. Thus, there is a need for lagged research designs to study the effects of job crafting behaviors over time (van den Heuvel et al., 2015) and to identify the long-term sustainability of the intervention effects (van Wingerden et al., 2017).

Finally, the embryonic stage of research on job crafting interventions offers some insights for future research. Studies were carried out mainly in the Netherlands and focused on few occupational groups. Therefore, further research should expand toward a broader range of national cultures and occupational groups. The research design limitations acknowledged by authors, indicated a call for producing more longitudinal designs that use bigger sample sizes and that integrate objective measures of job crafting behaviors (e.g., lateral and superior evaluations).

This systematic review also has limitations. A major limitation is the small number of studies included. We reviewed only peer-reviewed articles published in English and excluded other types of publications. The conclusions are preliminary as research on job crafting interventions is growing. A second limitation is the inconsistencies of findings across studies of the effects on outcomes of interests. We 
aimed to identify, describe, and analyze them. However, a further meta-analysis could advance research by summarizing the average effect size of job crafting interventions on each type of job crafting behavior and outcomes of interest.

We conclude that job crafting interventions have produced favorable effects on different types of job crafting behaviors and enhanced employee well-being and job performance. Future research can continue exploring and refining how different forms of job crafting behaviors, when promoted and stimulated, can produce positive outcomes at the workplace. Modern organizations worldwide are facing different challenges (e.g., talent retention and development, competition, structural changes, innovation, etc.). Therefore, job crafting interventions can be a valuable strategy to motivate employees to take charge in redesigning their own jobs to find better alignment with needs, abilities, and values, as well as an optimal job demands-resources balance. Job crafters may be more prone to keep work engagement and job performance high.

\section{References}

Bakker, A. B. (2015). Top-down and bottom-up interventions to increase work engagement. In P. J. Hartung, M. L. Savickas, \& B. W. Walsh (Eds.), APA Handbook of Career Intervention: Vol. 2. Applications (pp. 427-438). Washington, DC: American Psychological Association.

Bakker, A. B., \& Demerouti, E. (2017). Job demandsresources theory: Taking stock and looking forward. Journal of Occupational Health Psychology, 22(3), 273-285. doi: 10.1037/ ocp0000056

Demerouti, E. (2014). Design your own job through job crafting. European Psychologist, 19(4), 237247. doi: 10.1027/1016-9040/a00018888

Demerouti, E. (2015). Strategies used by individuals to prevent burnout. European Journal of Clinical Investigation, 45(10), 1106-1112. doi: 10.1111/ eci.12494

Demerouti, E., Xanthopoulou, D., Petrou, P., \& Karagkounis, C. (2017). Does job crafting assist dealing with organizational changes due to austerity measures? Two studies among Greek employees. European Journal of Work and
Organizational Psychology, 26(4), 574-589. doi: 10.1080/1359432X.2017.1325875

Grant, A. M., \& Parker, S. K. (2009). Redesigning work design theories: The rise of relational and proactive perspectives. The Academy of Management Annals, 3, 317-375. is pepidoi: 10.1080/19416520903047327

Janssen, O., Van de Vliert, E., \& West, M. (2004). The bright and dark sides of individual and group innovation: A special issue introduction. Journal of Organizational Behavior, 25(2), 129-145. doi: 10.1002/job.242

Kooij, D. T. A. M., van Woerkom, M., Wilkenloh, J., Dorenbosch, L., \& Denissen, J. J. A. (2017). Job crafting towards strengths and interests: The effects of a job crafting intervention on personjob fit and the role of age. Journal of Applied Psychology, 102(6), 971-981. doi: 10.1037/ ap10000194

Lichtenthaler, P. W., \& Fischbach, A. (2016). The Conceptualization and Measurement of Job Crafting. Zeitschrift für Arbeits-und Organisationspsychologie A\&O, 60, 173-186. doi: 10.1026/0932-4089/a000219

Meyers, M. C., van Woerkom, M., \& Bakker, A. B. (2013). The added value of the positive: A literature review of positive psychology interventions in organizations. European Journal of Work and Organizational Psychology, 22(5), 618-632. doi: 10.1080/1359432X.2012.694689

Nielsen, K., \& Abildgaard, J. S. (2012). The development and validation of a job crafting measure for use with blue-collar workers. Work \& Stress, 26(4), 365-384. doi: $10.1080 / 02678373.2012 .733543$

Niessen, C., Weseler, D., \& Kostova, P. (2016). When and why do individuals craft their jobs? The role of individual motivation and work characteristics for job crafting. Human Relations, 69(6), 12871313. doi: $10.1177 / 0018726715610642$

Petrou, P., Demerouti, E., Peeters, M. C., Schaufeli, W. B., \& Hetland, J. (2012). Crafting a job on a daily basis: Contextual correlates and the link to work engagement. Journal of Organizational Behavior, 33(8), 1120-1141. doi: 10.1002/ job. 1783

Rudolph, C. W., Katz, I. M., Lavigne, K. N., \& Zacher, H. (2017). Job crafting: A meta-analysis of relationships with individual differences, job characteristics, and work outcomes. Journal 
of Vocational Behavior, 102, 112-138. doi: 10.1016/j.jvb.2017.05.008

Sakuraya, A., Shimazu, A., Imamura, K., Namba, K., \& Kawakami, N. (2016). Effects of a job crafting intervention program on work engagement among Japanese employees: A pretest-posttest study. BMC Psychology, 4(1), 49. doi: 10.1186/ s40359-016-0157-9

Schaufeli, W. B., \& Taris, T. W. (2014). A critical review of the Job Demands-Resources Model: Implications for improving work and health. In Bridging occupational, organizational and public health (pp. 43-68). Dordrecht, Netherlands: Springer.

Sekiguchi, T., Jie, L., \& Hosomi, M. (2014). Determinants of job crafting among part-time and full-time employees in Japan: A relational perspective. Retrieved from https://ideas.repec. org/p/osk/wpaper/1426.html

Slemp, G. R., \& Vella-Brodrick, D. A. (2014). Optimising employee mental health: The relationship between intrinsic need satisfaction, job crafting, and employee well-being. Journal of Happiness Studies, 15(4), 957-977. doi: 10.1007/s10902-013-9458-3

Tims, M., \& Bakker, A. B. (2010). Job crafting: Towards a new model of individual job redesign. SA Journal of Industrial Psychology, 36(2), 1-9. doi: 10.4102/ sajip. v36i2.841

Tims, M., Bakker, A. B., \& Derks, D. (2012). Development and validation of the job crafting scale. Journal of Vocational Behavior, 80(1), 173-186. doi: 10.1016/j.jvb.2011.05.009

van den Heuvel, M., Demerouti, E., \& Peeters, M. C. W. (2015). The job crafting intervention: Effects on job resources, self-efficacy, and affective well-being. Journal of Occupational and Organizational Psychology, 88(3), 511-532. doi: 10.1111/joop. 12128

van Wingerden, J., Bakker, A. B., \& Derks, D. (2016). A test of a job demands-resources intervention. Journal of Managerial Psychology,
31(3), 686-701. doi: 10.1108/JMP-03-20140086

van Wingerden, J., Bakker, A. B., \& Derks, D. (2017a). Fostering employee well-being via a job crafting intervention. Journal of Vocational Behavior, 100, 164-174. doi: 10.1016/j.jvb.2017.03.008

van Wingerden, J., Bakker, A. B., \& Derks, D. (2017b). The longitudinal impact of a job crafting intervention. European Journal of Work and Organizational Psychology, 26(1), 107-119. doi: 10.1080/1359432X.2016.1224233

van Wingerden, J., Derks, D., \& Bakker, A. B. (2017). The impact of personal resources and job crafting interventions on work engagement and performance. Human Resource Management, 56(1), 51-67. doi: 10.1002/hrm.21758

Vogt, K., Hakanen, J. J., Brauchli, R., Jenny, G. J., \& Bauer, G. F. (2016). The consequences of job crafting: A three-wave study. European Journal of Work and Organizational Psychology, 25(3), 353-362. doi: 10.1080/1359432X.2015.1072170

Wrzesniewski, A. (2003). Finding positive meaning in work. In K. S. Cameron, J. E. Dutton, \& R. E. Quinn (Eds.), Positive organizational scholarship: Foundations of a new discipline (pp. 298-308). San Francisco, CA: BerrettKoehler.

Wrzesniewski, A., \& Dutton, J. E. (2001). Crafting a job: Revisioning employees as active crafters of their work. Academy of Management Review, 26(2), 179-201. doi: 10.5465/ AMR.2001.4378011

Wrzesniewski, A., LoBuglio, N., Dutton, J. E., \& Berg, J. M. (2013). Job crafting and cultivating positive meaning and identity in work. In Advances in positive organizational psychology (pp. 281-302). Bingley, UK: Emerald Group.

Received: $1 \% 02 / 2018$

$1^{\text {st }}$ revision: 07/06/2018 Accepted: 07/06/2018

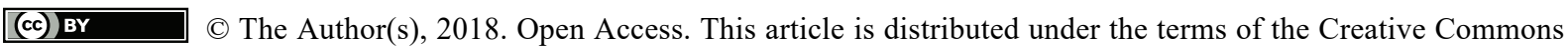
Attribution 4.0 International License (http://creativecommons.org/licenses/by/4.0/), which permits unrestricted use, distribution, and reproduction in any medium, provided you give appropriate credit to the original author(s) and the source, provide a link to the Creative Commons license, and indicate if changes were made. 